\title{
Effect of Speculators' Position Changes on the LME Futures Market
}

\author{
Jaehwan Park (D) \\ Commodity Research Center, Public Procurement Service, Daejeon 35208, Korea; drjppark@korea.kr; \\ Tel.: +82-210-3720-3967
}

Received: 19 March 2019; Accepted: 12 June 2019; Published: 14 June 2019

\begin{abstract}
This paper employs Granger causality tests to analyze the role of speculators using weekly COTR (commitment of traders reports) data covering the period of August 2014 to July 2017. The paper presents statistically significant evidence that the position changes of speculators, such as hedge funds and CTAs (commodity trading advisors), unidirectionally Granger-cause the prices of base metals, such as aluminum, copper, and zinc. This finding is a result of causality going from the levels of net futures positions of money managers to futures price changes on the London Metal Exchange (LME). However, producers' and swap dealers' speculative roles in price-formation are rejected in Granger causality tests. This paper presents clear results with important market implications.
\end{abstract}

Keywords: COTR; non-commercial traders; money managers; Granger causality test

JEL Classification: C3; G1

\section{Introduction}

Traditional discussion of commodity futures markets is in terms of hedgers and speculators (Gilbert 2010). The commodity futures markets have become important as investors regard commodity futures as an alternative asset class, comparable with equity and bonds (Tang and Xiong 2012). The coincidental and rapid rise in the prices of commodities and the increased number of financial investors in commodities futures markets between 2000 and 2008 have led certain observers to question whether speculators have distorted commodity prices. The key argument is whether the financialization (Cheng and Xiong 2014) of commodities markets distorts commodities prices ${ }^{1}$. Substantial attention from legislators (US Senate Permanent Subcommittee on Investigations USPSI ${ }^{2}$ ), academia, and news media have intensified the debate. Buyuksahin et al. (2009) reported that the rise in investments by non-commercial traders contributed to concurrent oil price increases in energy. Gilbert (2010) observed a statistically significant relationship between index fund trading and food prices in agriculture.

Alternatively, Sanders et al. (2010) observed that long-only index funds in agricultural futures markets might benefit from short hedging pressure but there was no strong implication that speculators drove agricultural commodities prices. Irwin and Sanders (2012) observed little evidence that

1 This is called the "Masters Hypothesis" by Irwin and Sanders (2012), in which long-only index investment was a major driver of the 2007-2008 spikes in commodities futures. Masters, a hedge fund manager, argued that massive buy-side 'demand' from index funds created a bubble in commodities prices in U.S. congressional hearings. He insisted that the recent speculators' behavior differed from that of traditional speculators. First, new investors took positions across the entire range of commodity futures, not in specific futures as traditional speculators did. Second, new investors were almost only long, whereas traditional speculators might equally be long or short.

2 The USPSI (US Senate Permanent Subcommittee on Investigations USPSI) concluded that there was significant evidence from the wheat futures market that one of the major reasons for unusual market price spikes is the high level of speculation by commodity index traders. 
speculators in commodities markets caused market prices to spike and determined no statistical causal links between returns and the positions of large energy exchange-traded index funds.

Most previous studies in this research area employed COT (commitments of traders) data, which are reported by the CFTC (commodity futures trading commission). The COT provides market data and position information on market participants who have positions in a specific futures market. Unlike energy and agricultural commodities, base metals are excluded from the COT data. This exclusion is the main reason why no previous study of base metals has been conducted in this study area.

The purpose of this paper is to examine data from the COTR (commitment of traders reports) to test the relationship between LME (London metal exchange) ${ }^{3}$ futures prices and the trading positions of various types of investors. This study conducts Granger causality tests and identifies a statistically significant link between money managers' position changes and subsequent returns in the LME market using weekly data from August 2014 to July 2017. Notice that the LME provides the market positioning data on a weekly basis beginning in August 2014. The empirical results suggest that the position changes of speculators have an unidirectionally strong Granger-cause on the LME futures prices. However, there is no evidence that producers' and swap dealers' position changes have a Granger-cause on the LME futures prices. There is statistically significant evidence: first, the evidence of a link between money managers' net position changes for aluminum, copper, and zinc prices, and second, the evidence of a link between money managers' net position changes to volatilities for only copper and zinc. Within this empirical result, it was found that copper and zinc face a somewhat higher risk among the LME's major six base metals from the speculators' trading pattern.

The rest of the paper is organized as follows. Section 2 reviews the previous literature. In Section 3 , the model is presented and a discussion is provided regarding how the Granger-causality hypothesis was set. In Section 4, the data set is illustrated and the main results are presented. Section 5 details the conclusions.

\section{Literature Review}

The role of speculators in commodity markets has been an issue of considerable interest and controversy (Brunetti et al. 2015). There has been no consensus about the impact of speculators on commodity futures markets. Singleton (2014), Buyuksahin and Robe (2009), Buyuksahin et al. (2009), and Gilbert (2010) found that speculators' impacts had a statistically significant effect on commodity futures prices, while Buyuksahin and Harris (2011), Sanders et al. (2010), and Irwin and Sanders (2012) found opposing results.

Singleton (2014) found that the largest impacts on futures prices were from intermediate-term growth rates of index positions and managed-money spread positions in oil futures markets. He also found that hedge fund trading in spread positions in futures influenced the shape of the term structure of oil futures prices. Buyuksahin and Robe (2009) showed that energy-equity co-movements increase amid greater participation in energy markets by, for example, hedge funds, but the impact of hedge fund activity is subdued during periods of financial turmoil. Buyuksahin et al. (2009) provided evidence for causal connections between non-commercial traders and oil prices. They found that the rise in participation by non-commercial traders during the preceding eight years (2000-2008) increased concurrent oil prices. Gilbert (2010) found that massive index-based investments in agricultural futures markets were seen as a major transmission channel through which macroeconomic and monetary factors generated the rapid food price rises between 2007 and 2008 using Granger causality analysis.

On the other hand, Buyuksahin and Harris (2011) highlighted that the role of speculators was the subject of heated debate, as oil futures price peaked at $\$ 147 /$ barrel in July 2008 . They employed COT

3 The LME is the world's largest futures exchange in the metal industry, including base metals and spot (cash), futures (3M), and various option contracts. Park and Lim (2018) provided a good discussion of the LME. They found that the LME was an inefficient market. 
data from US CFTC to test the relationship between oil prices and the trading positions of various types of traders in the oil futures market. They found little evidence that the speculators' position changes Granger-cause oil price changes. Irwin and Sanders (2012) found no statistically significant causal links between daily returns or volatility in the crude oil, and even natural gas futures markets and the positions for two large sample energy exchange-traded index funds using a Granger causality test. Brunetti and Buyuksahin (2009) did not find a statistical link between swap dealers' positions (a proxy for commodity index fund positions) and returns or volatility in the crude oil, natural gas, and corn futures markets using a Granger causality test. Sanders et al. (2010) showed that traditional speculation in agricultural futures markets using COT data did not influence returns. However, the long-only index funds might be beneficial, thanks to investments by speculators.

Park (2018) found that the evidence of volatility transmission between oil and base metals was somewhat strong, with a $1 \%$ significant level. He argued that considering this result, the behavior of volatility in oil and LME futures prices applied to hedge decisions across the commodity market was useful. Park and Lim (2018) reported that the LME market was not efficient due to the false premise that the financialization of commodities had been growing. This result implied that the LME futures market could generate somewhat possible excess returns, which could attract speculators such as hedge funds and CTAs (commodity trading advisors). Park (2019) argued that the canceled warrants (CWs) in the LME market were key indicators to explain the financialization effect in the market price directly. He pointed out that the CWs variable was crucial because it encompassed two factors-fundamentals and non-fundamentals. He found that the rise in CWs increased the LME metal prices, including aluminum, zinc, tin, and nickel. He found that the positive impact of the CWs on metal returns was transitory.

Arouri et al. (2011) exhibited the speculative efficiency of the aluminum contract traded in the LME using cointegration approaches. They found that futures aluminum prices were found to be cointegrated with spot prices and they were the biased estimators of future spot prices. In a somewhat different aspect, Figuerola-Ferretti and Gilbert (2008) reported the volatilities characteristics of aluminum and copper in LME. They found that aluminum and copper volatilities follow statistically long memory process, which were caused by speculative traders.

\section{Methodology}

Most previous articles in this study area have employed Granger causality tests to examine the effect of non-commercial traders on specific commodity market prices (Buyuksahin et al. 2009; Brunetti and Buyuksahin 2009; Gilbert 2010; Buyuksahin and Harris 2011; Irwin and Sanders 2012). The Granger causality test is based on a bivariate VAR (vector autoregressions) representation of stationary time series $\left\{X_{t}\right\}$ and $\left\{Y_{t}\right\}$ :

$$
\begin{aligned}
& X_{\mathrm{t}}=\mathrm{A}(\mathrm{L}) \mathrm{X}_{\mathrm{t}}+\mathrm{B}(\mathrm{L}) \mathrm{Y}_{\mathrm{t}}+\varepsilon_{\mathrm{X}, \mathrm{t}} \\
& \mathrm{Y}_{\mathrm{t}}=\mathrm{C}(\mathrm{L}) \mathrm{X}_{\mathrm{t}}+\mathrm{D}(\mathrm{L}) \mathrm{Y}_{\mathrm{t}}+\varepsilon_{\mathrm{Y}, \mathrm{t}}
\end{aligned}
$$

where $A(L), B(L), C(L)$, and $D(L)$ are lag polynomials. The null hypothesis is that "lagged $Y$ does not Granger-cause $X^{\prime \prime}$, while the alternative hypothesis is that "lagged $Y$ causes $X^{\prime \prime}$. The null hypothesis will be rejected if the coefficients on the lagged Y's are jointly significantly different from zero. Specification issues arise in relation to the choice of lag length because test results are sensitive to lag selection. To determine the optimal lag to be used in the VAR estimation, this paper employs the AIC (akaike information criterion) and SIC (Schwarz information criterion).

\section{Empirical Results}

\subsection{Data}

The main objective of this paper is to identify whether participation by some types of traders explains the extent to which the market moves as a consequence of investment money flows. This paper 
uses weekly COTR ${ }^{4}$ data from August 2014 to July 2017, which includes the trading positions of various types of investors, such as a money manager $(\mathrm{mm})$, broker-dealer/index trader $(\mathrm{bd})$, producer/merchant/user $(\mathrm{pm})$, and other reportable parameters. Money managers are engaged in managing LME contracts on behalf of clients, while broker-dealer/index traders are engaged in transactions and use the LME to manage or hedge the risk associated with those transactions (see details in the LME disaggregated reports). These data are used to compute net futures positions and evaluate percent changes against the previous week. For example, the variable mm_al is the weekly percent change in net position changes in the aluminum markettrackingcopper (cu), aluminum (al), lead (pb), zinc (zn), tin (sn), and nickel (ni). The benchmark futures price for base metals is that of a contract expiring after three months $(3 \mathrm{M})$, as obtained from Reuters over the same the period and computed using Thursday-Thursday ${ }^{5} \log$ returns to $3 \mathrm{M}$ futures prices. For example, the variable $\mathrm{r}_{-} \mathrm{al}$ denotes the weekly log returns in the aluminum market.

\subsection{Empirical Results}

Granger causality tests require variables to be stationary. To test stationarity, this paper employs the ADF (augmented dickey fuller) unit root test. Table 1 reports the ADF test results ${ }^{6}$. The table confirms that all variables are I (0), that is, stationary data. Therefore, the VARs (vector autoregressions) were ran in levels, rather than first differencing. The differencing non-stationary variables usually render them stationary.

Table 1. Unit root test results.

\begin{tabular}{cccccc}
\hline Metals & Variables & Statistics & Metals & Variables & Statistics \\
\hline \multirow{4}{*}{ Aluminum } & r_al & -14.09 & & r_cu & -12.60 \\
& mm_al & -13.18 & Copper & mm_cu & -12.86 \\
& bd_al & -14.23 & bd_cu & -12.57 \\
& pm_al & -9.935 & & pm_cu & -12.15 \\
\hline \multirow{2}{*}{ Zinc } & r_zn & -13.32 & & r_pb & -11.61 \\
& mm_zn & -9.293 & Lead & mm_pb & -11.92 \\
& bd_zn & -12.24 & & bd_pb & -9.940 \\
& pm_zn & -12.07 & & pm_pb & -11.74 \\
\hline \multirow{2}{*}{ Tin } & r_sn & -13.55 & & r_ni & -14.28 \\
& mm_sn & -12.69 & Nickel & mm_ni & -13.10 \\
& bd_sn & -12.33 & & bd_ni & -13.13 \\
& pm_sn & -13.02 & & pm_ni & -12.41 \\
\hline
\end{tabular}

Notes: There are 153 observations. (August 2014-July 2016; weekly data). Natural logarithms are used to calculate returns (r_al, r_cu, r_zn, r_pb, r_sn, and r_ni). The commitment of traders reports' (COTR's) position data are percent changes from the previous week (for example, $\mathrm{mm} \_\mathrm{al}$ : aluminum position changes of money managers, bd_al: aluminum position changes of broker-dealers, and pm_al: aluminum position changes of producers. Most previous studies utilized this method). The one percent critical value is -3.493 . The unit root tests show that all variables are $\mathrm{I}(0)$.

This paper analyzes Granger causality between weekly metal price changes and net position changes by including money managers, swap dealers, and producer groups, respectively. An initial hypothesis of Granger causality between LME metal price changes and position changes of only a money manager, rather than a broker-dealer/index trader or producer/merchant/user like most previous studies (Buyuksahin et al. 2009; Brunetti and Buyuksahin 2009; Gilbert 2010; Buyuksahin and

4 Six major base metals reports are published each Tuesday, one for each business day of the previous week. This data is obtained through the Bloomberg.

5 Thursday is the day the LME's COTR is announced.

6 Other unit root tests such as the Phillips-Perron (PP) test and Kwiatkowski-Phillips-Schmidt-Shin (KPSS) test have similar results. 
Harris 2011), was developed. A second hypothesis of Granger causality between LME metal price volatilities and position changes of money managers within the Irwin and Sanders (2012) framework was suggested. The idea is clear: if the investments of money managers drive metal prices, then price volatility may increase somewhat significantly. Hence, the hypotheses developed were as follows:

Hypothesis 1. The position changes of only a money manager are associated with LME metal price changes.

Hypothesis 2. The position changes of only a money manager are associated with LME metal price volatilities.

Pairs of variables were considered; the first member of each pair is an LME metal price movement, and the second is an investment flow of a specific group. As shown in Table 2, there are statistically significant unidirectional Granger causalities from metal price changes to net position changes of money managers. This finding is proof of positive feedback trading among money managers. Only aluminum, copper, and zinc exhibit bidirectional Granger causalities between metal price changes and net position changes of money managers. One of the probable reasons for this is liquidity, which means higher liquidity provides a better investment environment for money managers. Notice that the trading volumes of aluminum, copper, and zinc are relatively higher compared to other base metals in LME (see details in Park and Lim (2018)). This finding is strong and in line with the first hypothesis. The growth in hedge funds and commodity funds, such as major CTAs in the LME, has driven prices to be significantly higher. In addition, Park and Lim (2018) found that the LME market was inefficient, which could attract speculators. Buyuksahin et al. (2009) obtained a similar result in crude oil futures markets using Granger causality tests. Figure 1 depicts the trend of aluminum's net position for money managers and the LME aluminum price trend, which seem to be highly correlated with each other. Figures for other base metal prices and net positions of money managers are similar.

Table 2. Granger causality tests: First hypothesis.

\begin{tabular}{|c|c|c|c|c|c|}
\hline \multicolumn{3}{|c|}{ Aluminum } & \multicolumn{3}{|c|}{ Lead } \\
\hline $\begin{array}{l}\text { Causality } \\
\text { Direction }\end{array}$ & Lags & $p$-Value & $\begin{array}{l}\text { Causality } \\
\text { Direction }\end{array}$ & Lags & $p$-Value \\
\hline mm_al $\rightarrow$ r_al & 3 & $0.045^{* *}$ & $\mathrm{~mm} \_\mathrm{pb} \rightarrow \mathrm{r} \_\mathrm{pb}$ & 2 & 0.392 \\
\hline r_al $\rightarrow$ mm_al & 3 & $0.000^{* * *}$ & r_pb $\rightarrow$ mm_pb & 2 & $0.000 * * *$ \\
\hline$\overline{b d} \_a l \rightarrow r \_a l$ & 3 & $0.074 *$ & bd_pb $\rightarrow$ r_pb & 3 & 0.826 \\
\hline r_al $\rightarrow$ bd_al & 3 & 0.697 & r_pb $\rightarrow$ bd_pb & 3 & 0.665 \\
\hline pm_al $\rightarrow$ r_al & 3 & 0.700 & $\mathrm{pm} \_\mathrm{pb} \rightarrow \mathrm{r} \_\mathrm{pb}$ & 3 & 0.167 \\
\hline r_al $\rightarrow$ pm_al & 3 & $0.000 * * *$ & $\mathrm{r} \_\mathrm{pb} \rightarrow \mathrm{pm} \_\mathrm{pb}$ & 3 & 0.245 \\
\hline \multicolumn{3}{|c|}{ Copper } & \multicolumn{3}{|c|}{ Tin } \\
\hline $\begin{array}{l}\text { Causality } \\
\text { Direction }\end{array}$ & Lags & $p$-Value & $\begin{array}{l}\text { Causality } \\
\text { Direction }\end{array}$ & Lags & $p$-Value \\
\hline $\mathrm{mm} \_\mathrm{cu} \rightarrow \mathrm{r} \_\mathrm{cu}$ & 3 & $0.003^{* * *}$ & mm_sn $\rightarrow$ r_sn & 2 & 0.321 \\
\hline $\mathrm{r}_{-} \mathrm{Cu} \rightarrow \mathrm{mm} \_\mathrm{cu}$ & 3 & $0.006^{* * *}$ & r_sn $\rightarrow$ mm_sn & 2 & $0.000 * * *$ \\
\hline bd_cu $\rightarrow$ r_cu & 2 & 0.669 & bd_sn $\rightarrow$ r_sn & 2 & $0.032 * *$ \\
\hline $\mathrm{r} \_\mathrm{cu} \rightarrow$ bd_cu & 2 & 0.202 & r_sn $\rightarrow$ bd_sn & 2 & 0.467 \\
\hline pm_cu $\rightarrow$ r_cu & 2 & $0.086 *$ & pm_sn $\rightarrow$ r_sn & 2 & 0.315 \\
\hline r_cu $\rightarrow$ pm_cu & 2 & 0.450 & r_sn $\rightarrow$ pm_sn & 2 & 0.416 \\
\hline \multicolumn{3}{|c|}{ Zinc } & \multicolumn{3}{|c|}{ Nickel } \\
\hline $\begin{array}{l}\text { Causality } \\
\text { Direction }\end{array}$ & Lags & $p$-Value & $\begin{array}{l}\text { Causality } \\
\text { Direction }\end{array}$ & Lags & $p$-Value \\
\hline mm_zn $\rightarrow$ r_zn & 2 & $0.048^{* *}$ & mm_ni $\rightarrow$ r_ni & 2 & 0.103 \\
\hline r_zn $\rightarrow$ mm_zn & 2 & $0.042 * *$ & r_ni $\rightarrow$ mm_ni & 2 & $0.007^{* * *}$ \\
\hline
\end{tabular}


Table 2. Cont.

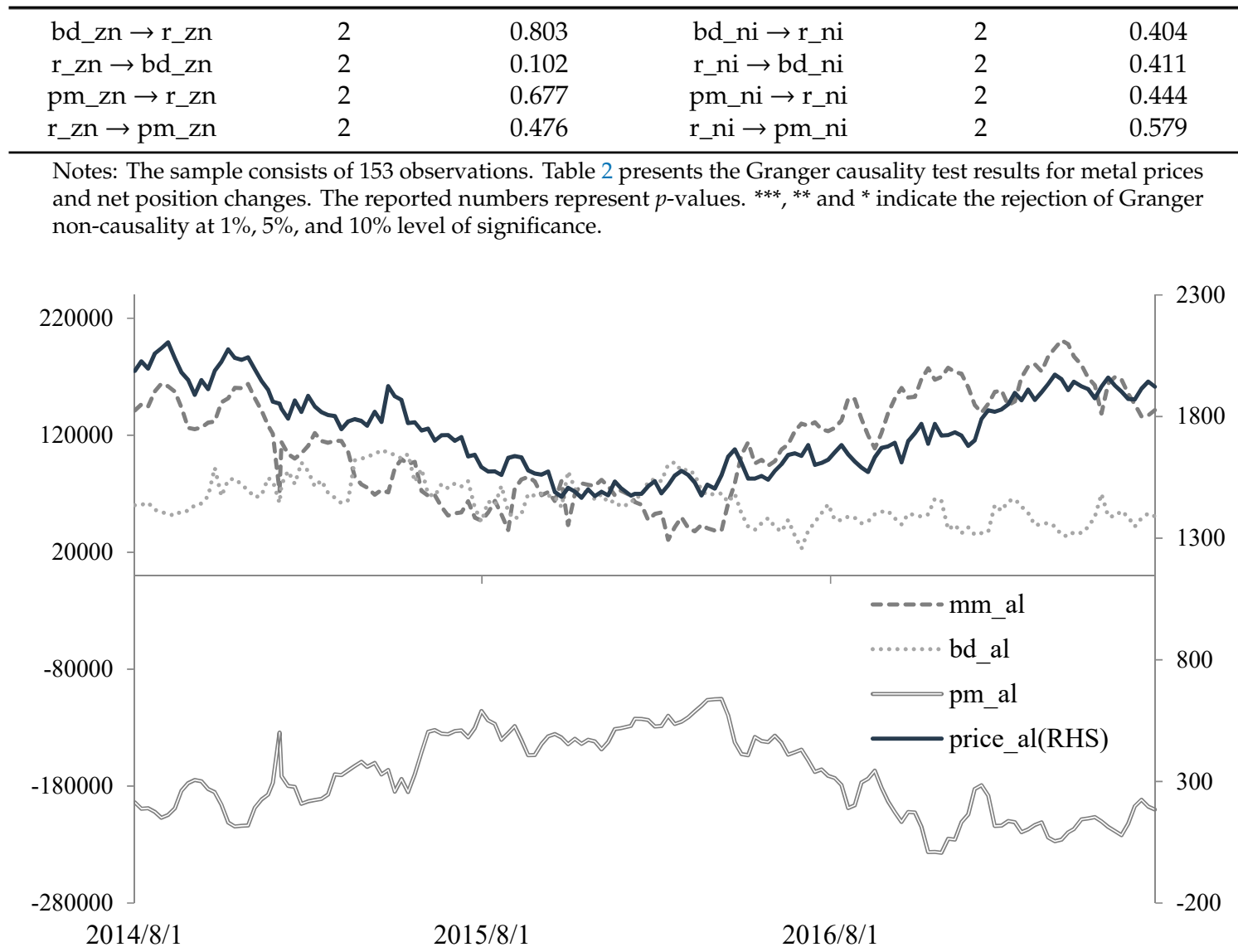

Figure 1. Plot of mm_al and price_al. Notes: The solid line is the price of aluminum on the LME over the period August 2014 to July 2017, while the bold dotted line is aluminum's net position trend for a money manager. The thin dotted line is aluminum's net position trend for a broker-dealer/index trader and the double line is aluminum's net position trend for a producer/merchant reveal with a somewhat different shape and indifferent from the price of aluminum.

Park and Lim (2018) evaluated the LME. First, the LME addresses daily rolling three-month futures contracts that are different from those in other commodity markets, which are based on monthly prompt dates. Second, the LME is traded electronically but is also traded through outcry, which is the oldest way of trading on the exchange. Park and Lim (2018) reported that these characteristics made markets inefficient and attracted speculators' investment money flows, which is in line with the result of this paper. Park (2019) concluded that the role of canceled warrants in the LME market intensifies the aluminum, zinc, tin, and nickel spot prices' direction. He argued that this evidence showed the financialization of the LME by speculative investors.

However, the tests for producer and index investors, similar to those employed for swap dealers, reject Granger causality. For the producer, the objective of investing in the LME futures market is purely hedging against price uncertainty. Figure 1 explains this result clearly. For the swap dealer front, Buyuksahin et al. (2009) note that they usually take positions using commodity index funds, which deliver returns based on the index and follow the herding mentality of unsophisticated traders, unlike active commodity funds. Therefore, the results for producers and index investors differ from those for money managers due to their own mandate characteristics. Indeed, the figures for base metal prices and net positions of producers and index investors reveal a somewhat different shape.

Table 3 examines the second hypothesis of Granger causality between metal price volatilities and net position changes of money managers within the research framework of Irwin and Sanders (2012). Notice that Irwin and Sanders (2012) used realized volatility and implied volatility within a similar 
empirical framework. The LME does not publish intra-day data or tick data. Hence, Figuerola-Ferretti and Gilbert (2008) argue that it is not possible to compute daily realized volatility measures for the LME market. This paper employs implied volatilities ATM (at-the-money) similarly to the work of Irwin and Sanders (2012) from Reuters as a measure of volatility. There is evidence of a link between money managers' net position changes and implied volatility in Table 3. Granger causality between the aluminum price volatility and position changes of money managers has been rejected. However, this causality has not been rejected for copper and zinc. It is found that copper and zinc are the only base metals that satisfy both hypotheses. In particular, a significant ( $p$-value $=0.04)$ is found between money managers' net position changes and implied volatility in zinc, which implies a somewhat higher risk in zinc due to money managers' speculative investment changes. Irwin and Holt (2004) find a small positive relationship between the hedge fund trading volume and volatility in thirteen different futures markets.

Table 3. Granger causality tests: Second hypothesis.

\begin{tabular}{ccc}
\hline Causality Direction & Lags & $p$-Value \\
\hline & Aluminum \\
\hline mm_al $\rightarrow$ iv_al & 2 & 0.166 \\
\hline iv_al $\rightarrow$ mm_al & 2 & 0.379 \\
\hline \multicolumn{3}{c}{ Copper } \\
\hline mm_cu $\rightarrow$ iv_cu & 2 & $0.084^{*}$ \\
\hline iv_cu $\rightarrow$ mm_cu & 2 & 0.161 \\
\hline & Zinc \\
\hline mm_zn $\rightarrow$ iv_zn & 3 & $0.048^{* *}$ \\
\hline iv_zn $\rightarrow$ mm_zn & 3 & 0.521 \\
\hline
\end{tabular}

Notes: The sample consists of 153 observations. Table 3 presents the Granger causality test results for net position changes by money managers and implied volatilities. The volatilities variables (iv_al, iv_cu and iv_zn) follow I(0) processes. The reported numbers represent $p$-values. ${ }^{* *}$ and ${ }^{*}$ indicate the rejection of Granger non-causality at $5 \%$ and $10 \%$ levels of significance.

Given this result, the question arises of why zinc has the most robust result. As Otto (2011) argued, the possible reason for this may be liquidity. Zinc had the third largest liquidity in terms of trading volume in the LME market. Unlike other base metals, zinc has a dominant production company, Glencore. Its market share of the total global production is more than $50 \%$ (Park and Lim 2018). These reasons provide a possible answer to the above question.

Testing the first (Table 2) and second (Table 3) hypotheses, this paper concludes that a rise in investment flows of money managers increases aluminum, copper, and zinc prices, but increases price volatility for only copper and zinc. However, there is no evidence that producers' and swap deals' position changes have a Granger-cause on the LME futures prices.

\section{Summary and Conclusions}

Utilizing weekly trader positions, Granger causality tests were examined to determine the relationship between price changes and net position changes of various traders in the LME futures market. This paper establishes two hypotheses concerning whether money managers' investment flows impact base metal prices and implied volatility. This analysis identifies categories of traders to assess how speculators relate to price changes and volatility. Using three years of weekly data, this paper observes that money managers' speculative investment changes influence LME metal prices for aluminum, copper, and zinc, exhibiting unidirectional Granger causality. Price changes lead the net position changes of speculators for all six base metals, which imply procyclical trading. However, 
there is no evidence that producers' and swap deals' position changes have a Granger-cause on the LME futures prices. This is a somewhat strong result.

For the second hypothesis, there is a significant Granger causality relationship between net position changes of speculators and implied volatility of the prices of copper and zinc. However, Granger causality is rejected for aluminum price volatility and position changes of money managers.

The failure to reject Granger causality has important implications for the pricing of LME futures. Even though fundamentals remain the major driver of base metals prices over the long-term, commodity fund activity tends to raise price volatility in the short-term. Over the last decade, and even until now, growing activity in commodities futures markets by major financial institutions, such as hedge funds, commodity index funds, and pension funds, has been witnessed.

Funding: This article received no external funding.

Acknowledgments: Hyeon Sook Kim, my colleague, provided the data set and gave useful comments. The author would like to thank three anonymous referees for their valuable comments and suggestions which contributed to the quality of this paper.

Conflicts of Interest: The author declares no conflicts of interest. The author alone is responsible for the context and writing of the paper.

\section{References}

Arouri, Mohamed El Hedi, Fredj Jawadi, and Prosper Mouak. 2011. The Speculative Efficiency of the Aluminum Market: A Nonlinear Investigation. International Economics 126-27: 73-89. [CrossRef]

Brunetti, Celso, Bahattin Buyuksahin, and Jeffrey H. Harris. 2015. Speculators, Prices and Market Volatility. Journal of Financial and Quantitative Analysis 51: 1545-74. [CrossRef]

Brunetti, Celso, and Bahattin Buyuksahin. 2009. Is Speculation Destabilizing? Working Paper. US CFTC. Available online: https://papers.ssrn.com/sol3/papers.cfm?abstract_id=1393524 (accessed on 12 June 2019).

Buyuksahin, Bahattin, and Jeffrey H. Harris. 2011. Do Speculators Drive Crude Oil Futures Prices? Energy Journal 32: 167-202. [CrossRef]

Buyuksahin, Bahattin, Michael S. Haigh, Jeffrey H. Harris, James A. Overdahl, and Michel A. Robe. 2009. Fundamentals, Trader Activity and Derivative Pricing. Working Paper. US CFTC. Available online: https://papers.ssrn.com/sol3/papers.cfm?abstract_id=966692 (accessed on 12 June 2019).

Buyuksahin, Bahattin, and Michel A. Robe. 2009. Commodity Traders' Positions and Energy Prices: Evidence from the Recent Boom-Bust Cycle. Working Paper. US CFTC. Available online: https://www.aeaweb.org/ conference/2010/retrieve.php?pdfid=355 (accessed on 12 June 2019).

Cheng, Ing-Haw, and Wei Xiong. 2014. Financialization of commodity markets. Annual Review of Financial Economics 6: 419-41. [CrossRef]

Figuerola-Ferretti, Isabel, and Christopher L. Gilbert. 2008. Commonality in the LME aluminum and copper volatility processes through a FIGARCH lens. Journal of Futures Markets 28: 935-62. [CrossRef]

Gilbert, C. 2010. How to understand high food prices. Journal of Agricultural Economics 61: 398-425. [CrossRef]

Irwin, S., and B. Holt. 2004. The impact of large hedge find and CTA trading on futures market volatility. In Commodity Trading Advisors: Risk, Performance Analysis and Selection. Hoboken: John Wiley and Sons, Inc., pp. 151-82.

Irwin, Scott H., and Dwight R. Sanders. 2012. Testing the Masters Hypothesis in commodity futures markets. Energy Economics 34: 256-69. [CrossRef]

Otto, S. 2011. A Speculative Efficiency Analysis of the London Metal Exchange in a Multi-Contract Framework. International Journal of Economics and Finance 3: 3-16. [CrossRef]

Park, J. 2018. Volatility Transmission between Oil and LME Futures. Applied Economics and Finance 5: 65-72. [CrossRef]

Park, J. 2019. The Role of Cancelled Warrants in the LME Market. International Journal of Financial Studies 7: 10. [CrossRef]

Park, Jaehwan, and Byungkwon Lim. 2018. Testing Efficiency of the London Metal Exchange: New Evidence. International Journal of Financial Studies 6: 32. [CrossRef] 
Sanders, Dwight R., Scott H. Irwin, and Robert P. Merrin. 2010. The adequacy of speculation in agricultural futures markets: Too much of a good thing? Applied Economic Perspectives and Policy 32: 77-94. [CrossRef]

Singleton, Kenneth J. 2014. Investor Flows and the 2008 Boom/Bust in Oil Prices. Management Science 60: 300-18. [CrossRef]

Tang, Ke, and Wei Xiong. 2012. Index Investment and the Financialization of Commodities. Financial Analysts Journal 68: 54-74. [CrossRef]

US Senate Permanent Subcommittee on Investigations (USPSI). 2009. Excessive Speculation in the Wheat Market; Washington: USPSI, June 24.

(C) 2019 by the author. Licensee MDPI, Basel, Switzerland. This article is an open access article distributed under the terms and conditions of the Creative Commons Attribution (CC BY) license (http://creativecommons.org/licenses/by/4.0/). 